Article

\title{
Cumulative Human Impacts on Coral Reefs: Assessing Risk and Management Implications for Brazilian Coral Reefs
}

\author{
Rafael A. Magris $1,2, *\left(\mathbb{D}\right.$, Alana Grech ${ }^{2}$ and Robert L. Pressey ${ }^{2}$ \\ 1 Chico Mendes Institute for Biodiversity Conservation, Ministry of Environment, \\ Brasilia DF 70.670-350, Brazil \\ 2 Australian Research Council Centre of Excellence for Coral Reef Studies, James Cook University, \\ Townsville QLD 4811, Australia; alana.grech@jcu.edu.au (A.G.); bob.pressey@jcu.edu.au (R.L.P.) \\ * Correspondence: rafael.magris@my.jcu.edu.au; Tel.: +55-61-2028-9032
}

Received: 2 February 2018; Accepted: 17 April 2018; Published: 24 April 2018

\begin{abstract}
Effective management of coral reefs requires strategies tailored to cope with cumulative disturbances from human activities. In Brazil, where coral reefs are a priority for conservation, intensifying threats from local and global stressors are of paramount concern to management agencies. Using a cumulative impact assessment approach, our goal was to inform management actions for coral reefs in Brazil by assessing their exposure to multiple stressors (fishing, land-based activities, coastal development, mining, aquaculture, shipping, and global warming). We calculated an index of the risk to cumulative impacts: (i) assuming uniform sensitivity of coral reefs to stressors; and (ii) using impact weights to reflect varying tolerance levels of coral reefs to each stressor. We also predicted the index in both the presence and absence of global warming. We found that $16 \%$ and $37 \%$ of coral reefs had high to very high risk of cumulative impacts, without and with information on sensitivity respectively, and $42 \%$ of reefs had low risk to cumulative impacts from both local and global stressors. Our outputs are the first comprehensive spatial dataset of cumulative impact on coral reefs in Brazil, and show that areas requiring attention mostly corresponded to those closer to population centres. We demonstrate how the relationships between risks from local and global stressors can be used to derive strategic management actions.
\end{abstract}

Keywords: cumulative impact assessment; coral reefs; Brazilian coast; human footprint; ecosystem management; climate change; overfishing; multiple stressors; marine planning; anthropogenic stressors

\section{Introduction}

Multiple stressors threaten coral reefs worldwide, causing severe declines of biodiversity and detrimental changes in the provision of associated ecosystem services [1-3]. Globally, coral reefs cover about 527,000 $\mathrm{km}^{2}$ [4], but in recent decades reefs have undergone extensive degradation [5], a trend expected to continue over the next century [6]. The stressors stem from a multiplicity of causes. Stressors with local causes include destructive fishing and increased sedimentation associated with runoff of land-based activities, which can be mitigated directly by managers when taking management actions on the land or sea. Stressors with global causes, such as global warming and ocean acidification, cannot be directly addressed by managers, although their effects can be mitigated by local management $[1,7]$. The dramatic degradation of coral reefs necessitates rational, accountable, cost-effective conservation management to counteract both types of stressors. This is particularly important in developing countries where high dependence on marine resources [8] creates strong competition between short-term social and commercial interests and longer-term concern for environmental conservation. 
One of the most pervasive stressors for coral reefs is global warming. Coral reefs are among the earliest ecosystems to show marked ecological responses to global warming [2], and such sensitivity increases the extinction risk for many species [9]. Global-warming disturbances on coral reefs are expected to include reduced coral growth [10], decreased capacity to recover from a suite of other stressors [2], mass coral mortality associated with bleaching events [11], shifts in species ranges [12], and coral disease outbreaks [13]. The mechanisms controlling larval dispersal and their relationships with environmental conditions are also sensitive to climate change [14,15]. All these broad-scale changes affect entire coral reef ecosystems, resulting in declines in biodiversity, fisheries yield, and other ecosystem services. Consequently, pragmatic conservation actions are required to address new challenges to conserving coral reef ecosystems in face of unprecedented and unstoppable sea-temperature warming.

Several studies have provided insights into the empirical responses of coral reef assemblages to multiple stressors [16-18]. Additionally, recent studies have proposed approaches to understanding the multiple interactions between local and global stressors and their importance for cumulative impact assessment (CIA) [19-21]. Although integrating the potential effects of interacting multiple stressors is of utmost importance for conservation management [20], a first step towards a comprehensive CIA is quantifying the distribution and intensity of total regional human footprint. The impact of that footprint can be estimated by measuring the differential sensitivity of ecosystems to multiple stressors. Stressor mapping studies have been mostly developed at global scales [22,23], and only rarely has detailed mapping of human footprint been attempted at regional scales with data at a similar spatial grain to the ecological processes being threatened, even though such studies are increasingly necessary.

As in many other regions, coral reefs in Brazil are under pressure from multiple disturbances caused by local [24] and global stressors [25] (Figure 1). Brazilian coral reefs are also considered of high global conservation value owing to their high species endemism [26], the presence of many threatened species [27], and their unique geomorphologic formation, which is significantly different from the well-known coral reef ecosystems of the Caribbean and Indo-Pacific regions [28]. Despite high conservation values, these ecosystems have undergone little conservation planning [29]. Brazilian coral reefs are also warming faster than the global average in many areas [25,30], and local pressures on these ecosystems are increasing as marine species are rapidly depleted [27,31]. Nowadays, there is a high social and economic dependence on Brazilian coral reef resources, especially for fisheries [32] and tourism [33]. This situation creates an imperative for comprehensive cumulative assessment and sustainable use of biodiversity.
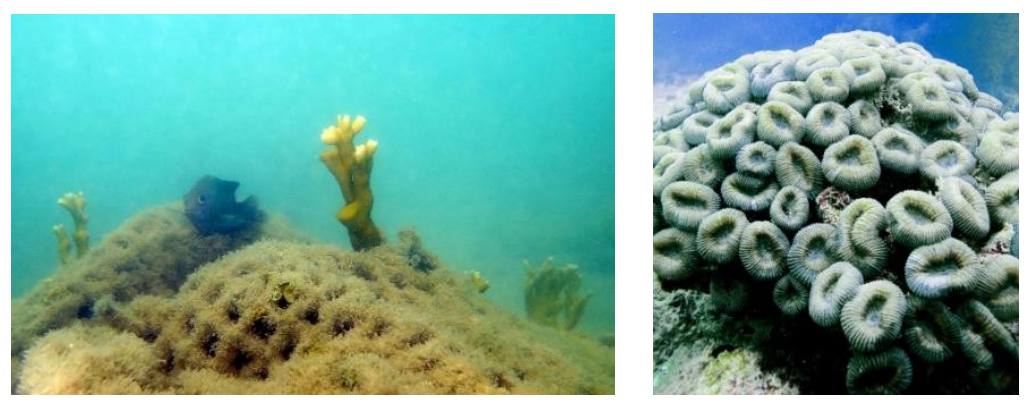

Figure 1. Degraded coral reefs in Brazil. A mix of local and global stressors threaten reefs, leading to a phase shift to algal-dominated reefs (left) and severe bleaching (right). Photographic credit: Pedro H.C. Pereira.

This study aims to take the first major step towards a comprehensive CIA of Brazilian coral reefs that could help inform future conservation planning efforts. From this, management recommendations on areas facing the highest potential cumulative impact can be made. Importantly, identifying coral reefs least exposed to multiple stressors can also aid in spatial prioritisation aiming to maintain biodiversity over time. By quantifying the total human footprint for a set of stressors and estimating 
risks to cumulative impacts, we are building foundations for more refined, predictive knowledge of human impacts on the structure and dynamics of coral reef ecosystems in Brazil. We anticipate that some coral reefs identified as refugia from both local and global stressors and candidates to be thus protected. Conversely, large coral reef areas would need to be particularly targeted for specific management actions (i.e., stress alleviation from local stressors, ecological monitoring, or ecosystem restoration) according to their susceptibility to different combinations to impacts from local and global stressors.

\section{Materials and Methods}

We collated publicly-available data on local and global stressors known to exert significant impacts on coral reefs $[1,34,35]$ within our study area (Brazilian reefs; Figure 2): (i) fishing intensity; (ii) land-based activities (e.g., infrastructure, agriculture, pasture and urban areas); (iii) coastal development; (iv) ocean mining (i.e., lime, sand mining, oil and gas exploration); (v) aquaculture (shrimp farming); (vi) shipping movements; and (vii) thermal stress. Data on stressors were summarised within 2276 reef cells, each one a squared-grid of $1 \mathrm{~km}^{2}$ containing varying extents of coral reef habitat (see top inset of Figure 2). We mapped how susceptible a particular reef cell was to pressures from each stressor (henceforth termed 'exposure') following the framework proposed by [36].

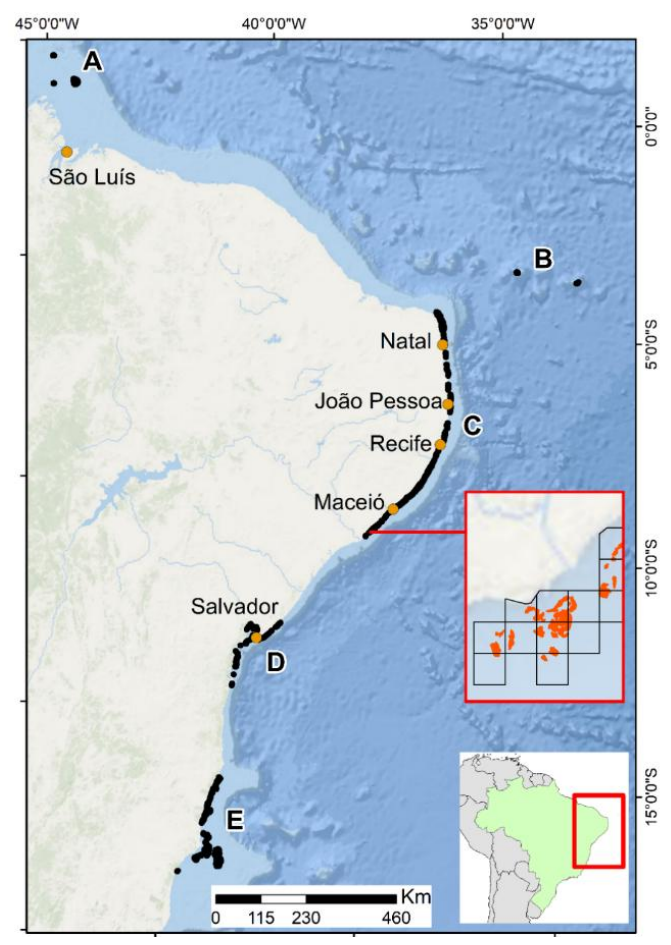

Figure 2. The study area and the reef cells $(n=2276)$, each one a squared-grid of $1 \mathrm{~km}^{2}$ containing coral reef habitat. Top inset is a zoomed view of reef cells containing coral reef habitat (depicted as orange patches). Coral reefs in Brazil occur in five geographically distinct sectors: (A) Parcel Manuel Luis; (B) Fernando de Noronha and Atoll das Rocas; (C) Northeastern coast; (D) Todos os Santos Bay; and (E) Abrolhos Bank.

\subsection{Mapping the Exposure to Multiple Stressors}

To characterise the exposure of reefs to multiple stressors, we gathered data on each stressor separately. Details on how the exposure to each stressor was calculated are found in the Appendix A. Below, we briefly describe each layer and provide information on datasets, types of data, and analyses involved in Table 1. 
Table 1. Description of each stressor layer used for cumulative impact assessment (CIA) of Brazilian coral reefs.

\begin{tabular}{|c|c|c|c|c|}
\hline Stressor & Justification for Stressor & Source of Dataset & Scaling of Data & Data Model and Attributes \\
\hline Fishing FII & $\begin{array}{l}\text { The wholesale removal of reef fish species } \\
\text { causes severe depletion of populations and } \\
\text { impairs coral reef resilience [37] }\end{array}$ & $\begin{array}{l}\text { Google Earth Pro and } \\
\text { government reports } \\
\text { described in [38] }\end{array}$ & Continuous & $\begin{array}{l}\text { Linear decay model based on mapping } \\
\text { the spatial location of } 3610 \text { traditional } \\
\text { and } 65 \text { industrial active vessels }\end{array}$ \\
\hline Land-based activities LAI & $\begin{array}{l}\text { These activities are proven to increase } \\
\text { erosion and deteriorate coastal water } \\
\text { quality, changes that cause detrimental } \\
\text { impacts on coral reef species [39] }\end{array}$ & $\begin{array}{l}\text { Land-use data, infrastructure, } \\
\text { and human access to natural } \\
\text { areas in the terrestrial } \\
\text { environment described in } \\
\text { [40,41] and river plume data } \\
\text { (Appendix A) }\end{array}$ & Continuous & $\begin{array}{l}\text { Raster dataset containing the human } \\
\text { footprint score derived from several } \\
\text { variables (e.g., crop land, extent of built } \\
\text { environments, and roads) measuring the } \\
\text { direct and indirect human pressures on } \\
\text { coastal catchments; Euclidean distance } \\
\text { from each reef cell centroid to mouth of } \\
\text { the nearest main river }\end{array}$ \\
\hline Coastal develop-ment CDI & $\begin{array}{l}\text { Coastal development results in sewage } \\
\text { discharge, urbanisation, presence of } \\
\text { engineering structures, and other } \\
\text { general uses of the shore that can } \\
\text { disrupt coral reef ecosystems }[42,43]\end{array}$ & $\begin{array}{l}\text { DMSP/NOAA/NGDC } \\
\text { nighttime satellite imagery } \\
\text { as described in }[38,44]\end{array}$ & Continuous & $\begin{array}{l}\text { Relative distance from each reef cell } \\
\text { (centroid) to a source of night-time } \\
\text { light (based on the metric LPI } \\
\text { (light proximity index) }\end{array}$ \\
\hline Ocean mining OMI & $\begin{array}{l}\text { Physical structures for mineral } \\
\text { extraction promote habitat loss. } \\
\text { Indirect impacts include nutrient } \\
\text { loading and sedimentation [45] }\end{array}$ & $\begin{array}{l}\text { Government databases publicly } \\
\text { available (Appendix A) }\end{array}$ & $\begin{array}{c}\text { Categorical } \\
\text { (presence or absence) }\end{array}$ & $\begin{array}{l}\text { Vector data set of spatial locations of } \\
\text { areas converted for mining }(n=70) \text { as } \\
\text { well as areas beyond their physical } \\
\text { presence under indirect exposure }\end{array}$ \\
\hline Aqua-culture ADI & $\begin{array}{l}\text { An important source of organic and } \\
\text { inorganic pollution, often associated with } \\
\text { eutrophication of coastal waters [46] }\end{array}$ & $\begin{array}{l}\text { Shrimp farm locations } \\
\text { mapped by [47] }\end{array}$ & Continuous & $\begin{array}{l}\text { Euclidean-distance-based model from the } \\
\text { centroid of each farm pond }(n=115) \text { that } \\
\text { would potentially affect a given reef cell }\end{array}$ \\
\hline Shipping move-ments SMI & $\begin{array}{l}\text { Shipping-associated disturbances such } \\
\text { as sediment resuspension and noise } \\
\text { pollution lead to habitat degradation [48] }\end{array}$ & $\begin{array}{l}\text { Shipping activity including } \\
\text { domestic and international } \\
\text { fleet and several vessel } \\
\text { types made available by } \\
\text { Marine Traffic (Appendix A) }\end{array}$ & $\begin{array}{l}\text { Categorical (low, medium, } \\
\text { high, and very high) }\end{array}$ & $\begin{array}{l}\text { Density map classifying levels of } \\
\text { ship movement based on historical } \\
\text { data on ship positions }\end{array}$ \\
\hline Thermal stress TSI & $\begin{array}{l}\text { Sea-surface temperature is associated } \\
\text { with coral bleaching and several other } \\
\text { ecological shifts in coral reef ecosystems [2] }\end{array}$ & $\begin{array}{l}\text { Sea surface temperature } \\
\text { data obtained from NOAA } \\
\text { and described by [25] }\end{array}$ & Continuous & $\begin{array}{l}\text { Rate of warming using non-linear mixed } \\
\text { effect models based on monthly } \\
\text { climatology of sea surface temperature. }\end{array}$ \\
\hline
\end{tabular}


The fishing intensity index was derived from the mapping methods developed by [49] and adapted to the Brazilian context by [38], where the potential exposure to traditional and industrial fisheries was estimated based on a decay factor function that combines information on vessel transits and fisher behaviour. For land-based activities, the exposure index was derived from the summed human footprint score $[40,41]$ in coastal catchments as a proxy for potential pollution supply associated with human land uses and its influence in coastal waters. The coastal development index was calculated as described by [44], whose index was measured by distance from emission of night-time lights. The presence of ocean mining activity and its area of influence (a discrete buffer width around each location) was assigned to each reef cell based on a layer containing all mining fields. The exposure to aquaculture-related disturbances was quantified by a Euclidean distance-based model in which stress declines as distance to shrimp farms increases. For shipping movement, the exposure was mapped using the network density of cargo ship movements. The spatial pattern of thermal stress was based on the rate of sea-surface temperature rise that was calculated by applying nonlinear mixed effect modelling [25].

\subsection{Composite Index of the Cumulative Impact on Coral Reefs}

Having mapped the exposure of reef cells to all stressors, we combined each of the stressors presented above in GIS, to produce a composite index of the risk to cumulative impacts on coral reefs (CIR). For this step, each stressor layer was normalised to range between 0 and 1 , where 1 reflected the maximum value of exposure across all reef cells throughout study area for each layer and 0 indicated the minimum value of exposure. This normalisation made it possible to compare all layers. Following the approach of $[22,50,51]$ and others, this study assumed that the cumulative impact of multiple stressors was additive rather than synergistic or antagonistic. Since additive models are more conservative and simple to use in terms of estimating pressure interactions, they are most commonly used in CIA [52]. The index for each $1 \mathrm{~km}^{2}$ reef cell was calculated as:

$$
\mathbf{C I R}=a \mathbf{F I}+b \mathbf{L A I}+c \mathbf{C D I}+d \mathbf{O M I}+e A D I+f S M I+g T S I
$$

where $F I I$ is the fishing index, $L A I$ is the index of exposure to land-based activities, $C D I$ is the coastal development index, $O M I$ is the index of exposure to mining activities, $A D I$ is the index of exposure to aquaculture activities, SMI is the shipping-movement index, and TSI the thermal stress index; and $a-g$ are constants. We used two approaches to incorporate estimates of sensitivity of coral reefs to multiple stressors. The first approach assumed equal weighting of stressors, i.e., the seven stressors were weighted by a series of constants $(a-g)$, each with a value of 1 . The second approach assumed that coral reefs had differing sensitivities to each stressor, i.e., variable weights to reflect the relative sensitivity of coral reefs to each stressor were used. Stressor weightings dictate how species differ in their ability to tolerate each stressor. The impact weights of sensitivity of coral reefs to stressors in the second approach were derived from [53] and presented in Table 2. Halpern et al. [53] developed a systematic framework for collecting expert opinion on the relative impact of multiple pressures on marine ecosystems. The vulnerability of ecosystems to individual pressures was characterized by five attributes (termed 'vulnerability factors'). A ranking system was then used to quantify the score of each vulnerability factor, and combining the five scores provided a relative estimate of the sensitivity of environmental features to anthropogenic stressors (i.e., Table 2). Similarly to calculating each stressor individually, values of each index were standardized between 0 and 1, indicating minimum and maximum risks of cumulative impact, respectively. We represented the resulting scores into one of the five categories: very low (0-0.2), low (0.2-0.4), medium (0.4-0.6), high (0.6-0.8), and very high (0.8-1).

We also sought to compare risks of impacts from local stressors with risks of impacts from global stressors. For this last set of analyses, we recalculated the risk to cumulative impacts as in our second approach above, omitting the thermal stress index (TSI) from equation 1 to yield $\mathrm{CIR}_{\mathrm{L}}$. The values of $\mathrm{CIR}_{\mathrm{L}}$ represented the risk to cumulative impacts from local stressors only and were plotted against the 
sole risk of impact from warming disturbances (termed ' $\mathrm{CIR}_{\mathrm{G}}{ }^{\prime}$ ). $\mathrm{CIR} \mathrm{R}_{\mathrm{G}}$ was obtained by multiplying the exposure to thermal stress (TSI) by the constant $g$ in Table 2 followed by normalization (as indicated above). We proposed that plotting relative risks from local stressors against relative risks from global stressors might help indicate more nuanced management strategies for coral reefs. We then split the scatterplot of local and global stressors in four quadrants (distinguished by the intersection of lines where $\mathrm{CIR}_{\mathrm{L}}$ and $\mathrm{CIR} \mathrm{R}_{\mathrm{G}}$ scores were 0.5 ) and suggested four main management strategies: (i) protection, when both $C I R_{L}$ and $\mathrm{CIR}_{\mathrm{G}}$ are relatively low (i.e., less than 0.5 ) and thus ecosystems are more likely to be naturally-functioning entities; (ii) removal or mitigation of local stressors, when both $\mathrm{CIR}_{\mathrm{L}}$ and $\mathrm{CIR}_{\mathrm{G}}$ are relatively high (i.e., greater than 0.5 ) and thus coral reefs would have reduced ability to cope with both sources of stress unless managers alleviate stress from locally manageable sources; (iii) ecosystem change monitoring, when only $\mathrm{CIR}_{\mathrm{G}}$ is relatively high and thus ecosystems might experience less confounding effects from local stressors, while making mechanisms associated with the responses to warming easier to interpret; and (iv) restoration prioritisation, when only $\mathrm{CIR}_{\mathrm{L}}$ is relatively high and thus effectiveness of management actions through restoration can be enhanced because only stoppable stressors are operating.

Table 2. Stressor weightings when calculating cumulative impact of stressors on coral reef ecosystems.

\begin{tabular}{ccc}
\hline Stressor & Constants Used in the Formula Above & Weights \\
\hline Fishing intensity & $a$ & 2.5 \\
Land-based activity & $b$ & 2.8 \\
Coastal development & $c$ & 2.9 \\
Ocean mining & $d$ & 0.8 \\
Aquaculture & $e$ & 1.8 \\
Shipping movement & $f$ & 1.5 \\
Thermal stress & $g$ & 2.8 \\
\hline
\end{tabular}

\section{Results}

We found that some reef cells were facing the maximum level of exposure (e.g., FII or TSI equal to 1 ) to each stressor (Figure 3). Among all stressors, thermal stress and fishing accounted for the two largest average values of exposures, with means of 0.53 (median $=0.48$ ) and 0.32 (median $=0.25$ ), respectively. The northeastern coast, Todos os Santos Bay, and the nearshore reefs of Abrolhos Bank (sectors C, D, and E of Figure 2, respectively) contained the highest concentration of cells with high levels of exposure to fishing and land-based activities (Figure S1). In contrast, the spatial distribution of cells with exposure to ocean mining was limited (about $4 \%$ of total number of reef cells-almost all from sector D, Figure S2). This stressor also had the smallest mean and median values of exposure. The exposure to coastal development was diffuse and closely coincident with the location of the main cities along the northeastern coast and Todos os Santos Bay (sectors C and D of Figure 2, respectively) (Figure S2). The exposure to aquaculture was more concentrated in the sectors C and D of Figure 2 while exposure to shipping movement was more pronounced over the offshore and nearshore reefs situated in the sectors A and E, respectively (Figure S3). Thermal stress had the most widespread distribution of cells containing high levels of exposure (Figure S4). Only a few reef cells had low exposure to global warming (mostly from reefs situated in sector D).

Approximately $16 \%$ of reef cells had high to very high risk of experiencing cumulative impacts when assuming equal sensitivity of coral reef ecosystems across stressors (cells coloured in red and orange in Figure 4a). When variable sensitivities across stressors were included, 37\% of reef cells had high to very high risk to cumulative impacts (cells coloured in red and orange in Figure $4 \mathrm{~b}$ ). A comparison between the two approaches also showed distinct spatial distributions of reefs with high or very high risks of cumulative impacts. For the first approach, these cells were mostly restricted to sectors $C$ and $D$ of the study area. For the second approach, areas of high to very high risk for cumulative impacts became widespread throughout the study area (only sector A contained reef cells 
that remained with low risks to cumulative impacts). Overall, the spatial distribution of reefs with high or very high risks was largely coincident with the presence of localities where human population is high (see location of major capital cities in Figure 2). Global stressors also seemed to drive much of the risk in the study area. For example, southern reefs in the Abrolhos Bank displayed higher risks than northern reefs owing to their enhanced warming trend observed (Figure S4).

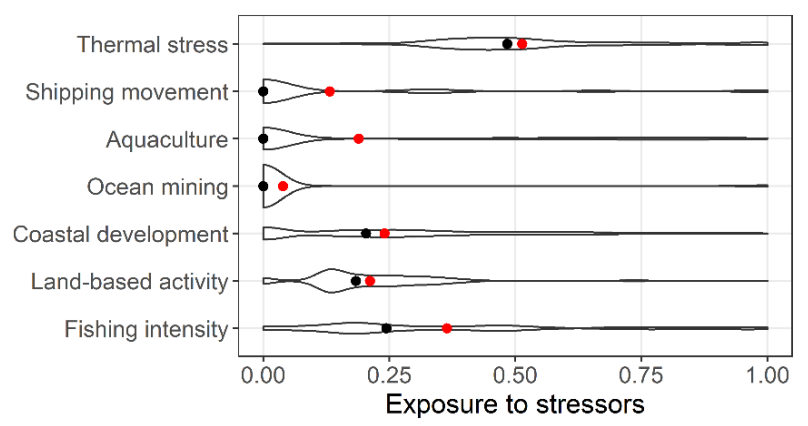

Figure 3. Exposure of Brazilian reefs to individual stressors. Violin plots depict the variation in levels of reef cell exposure to each stressor from low (i.e., 0 ) to high (i.e., 1). Red dots represent the mean level of exposure while black dots represent the median.

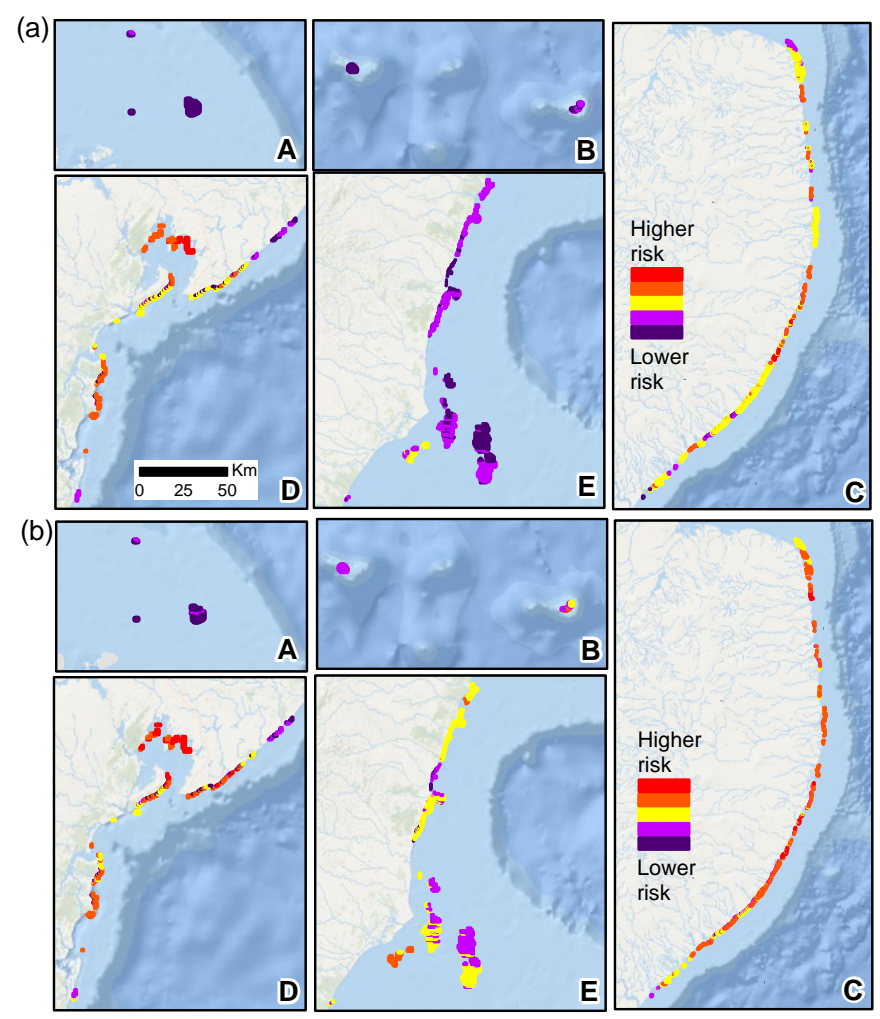

Figure 4. Spatial distribution of the risk to cumulative impacts across reef cells disregarding (a) or considering (b) variable sensitivity to stressors (fishing, land-based activities, coastal development, ocean mining, aquaculture, shipping movements, and thermal stress). The gradient of colours indicates five classes of risk to cumulative impacts ranging from the relatively very low risk in purple to very high risk in red. Panels (A-E) correspond to the locations of five geographically distinct sectors showing in Figure 1.

Given the pervasive spatial patterns of stressors, it was surprising that a considerable number of reef cells (i.e., about $42 \%$ ) had low risk to cumulative impacts from both local and global sources of 
stress (bottom left-hand side of the Figure $5 a, b)$. They were mostly nearshore banks situated further south (sector E), but also included few reefs in sector A (Parcel Manuel Luis), B (Fernando de Noronha Island), C (e.g., Parrachos de Rio do Fogo, northern Rio Grande do Norte) and D (Peninsula de Maraú and northern Bahia). Only $6.5 \%$ of reef cells identified as having a high risk of cumulative impact overlapped between the two types of stressors (top right-hand side of the Figure $5 a, b)$. We also found a considerable number of reef cells facing high-level risk to cumulative impacts from global stressors only (i.e., about $37 \%$ ), which might be targeted for specific conservation actions such as biodiversity monitoring. Lastly, about $14.5 \%$ of reef cells had high-level risk to impacts solely related to local stressors and could be prioritised for restoration strategies.

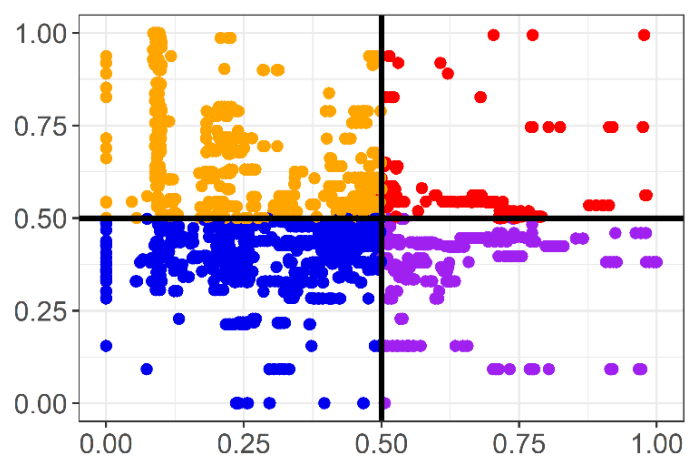

(a)

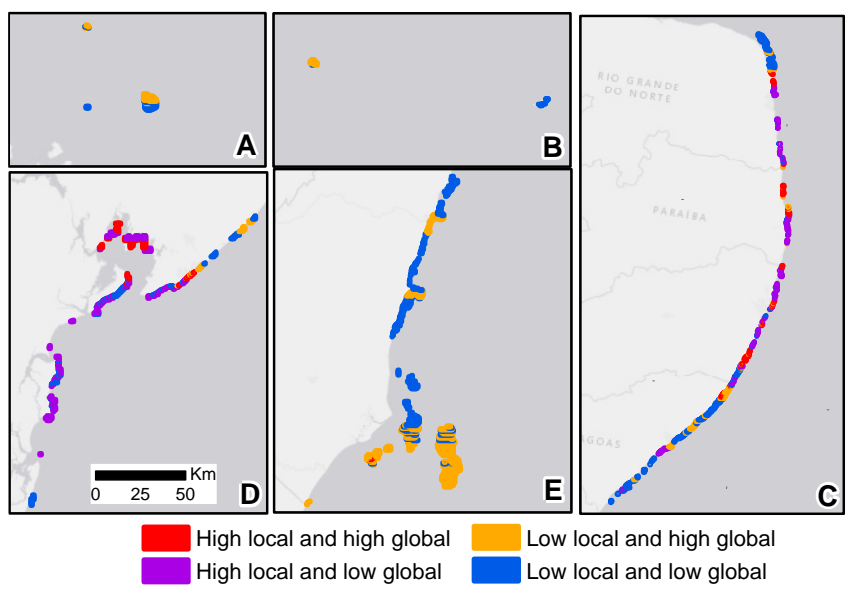

(b)

Figure 5. Local and global stressors. Comparison of the levels of risk to cumulative impacts on each reef cell between local ( $x$-axis) and global sources of stress ( $y$-axis) (a). Dots in blue represent the overlaps between low risks of cumulative impact from local and global stressors and might indicate candidate areas for protection. Dots in red are high priorities for stress alleviation from locally manageable sources. Dots in orange are high priorities for ecosystem change monitoring and represent reef cells with high-risk impacts from global stressors only. Dots in purple indicate reef cells with high-risk impacts from local stressors only and might be considered priorities for restoration. Spatial distribution of reef cells based on different combinations of risks to impacts from local and global stressors separately (b). Colours are the same as in (a). Panels (A-E) correspond to the locations of five geographically distinct sectors showing in Figure 2.

\section{Discussion}

Planning management actions considering the interplay between multiple stressors remains a major gap in conservation science [54], especially because the scale and extent of impacts on marine biodiversity are staggering [3,23]. This study sought to fill this gap by: (i) acknowledging that coral 
reefs vary their response to individual stressors, which results in an increase in the amount of coral reef habitat classified as high risk to cumulative impacts; and (ii) developing a framework that allow planners to determine management actions on the basis of relationships between risks to impacts derived from local and global stressors distinctly. Although we have developed our dataset for Brazilian coral reefs, this same approach can help improve the effectiveness of management actions undertaken within any given region. While we found evidence that some coral reefs are refugia from human interference, the present study also showed that an extensive tract of this ecosystem requires different management strategies to cope with reef degradation. Rather than serve only as a methodological framework to assist planners in fine-tuning their approaches, we strongly advocate these data be used to inform conservation planning and to assess current conservation efforts.

Two stressors seemed to play a prominent role, potentially affecting a large amount of coral reef habitat within our study area. These were thermal stress and fishing activities. Although there is a paucity of field data on bleaching events in Brazil [25], global warming is associated with severe historical impacts including extensive mortality [55] and the incidence of coral diseases [56]. Similarly, the effects of local-scale fishing pressure in Brazil have been rarely studied (but see [57]). Also, data on fishing activity at a scale suitable for management have not been collected since 2007 [58]. Small-scale fisheries have proven to be particularly difficult to assess and manage [59], making the serious impacts on Brazilian reefs likely to worsen. A combination of continuous degradation and lack of high-resolution data that are always scarce in developing countries can lead to substantial depletion of marine biodiversity. Under such circumstances, remotely sensed data represent an important source of information that can be readily acquired to inform regional CIA, as illustrated in this paper.

Spatially-explicit approaches to CIA use the spatial modelling and overlay functions of GIS to map the exposure and intensity of multiple stressors, and to quantify the overlap of stressors and environmental features (e.g., [22,23,50,60-64]). There are multiple sources of error that affect accuracy and precision in the spatial data used to inform CIA, including scale, age of data, measurement errors and positional accuracy. Other sources of error in the spatial component of CIA are a product of assumptions in the analysis, including [65]: the components of stressors are of equal importance (e.g., "fishing" is a combination of multiple fishing types including line, trawl and netting), the distribution of stressors is uniform within a grid, and transforming and normalising data is an appropriate representation of stressor distribution and exposure. All of these errors combine to reduce the certainty in predictions of impact and risk in spatially-explicit CIA.

In addition to spatial information, a measure of the sensitivity of environmental features to stressors is used in CIA to assess the cumulative impact of multiple stressors. Precise quantitative information and empirical data on the sensitivity of environmental features to stressors are rarely available, especially at broad spatial scales [36]. A major cause of this data deficiency is the paucity of empirical studies evaluating the impact of multiple stressors with enough length of historical data to have been refined based on expert input [52]. The primary source of information on sensitivity is expert knowledge, generally recorded using structured elicitation approaches (e.g., [53,66,67]). The impact weights used in this study were derived from an expert survey, published in [53]. Despite the attempt by [53] to minimise bias by capturing the opinions of a large number of experts using a structured approach, outputs of the survey are inevitably affected by biases in expert judgement [68] and deficiencies in the method used to extract judgements [69].

We assumed that the cumulative effect of multiple stressors was additive. Crain et al. [52] reviewed studies on the interactive and cumulative effects of multiple human stressors in marine systems and found the relationship can be additive, synergistic, and antagonistic; and the number of synergistic interactions doubles when three or more threats are present. The findings of [52] have implications for our results because synergisms between pressures may amplify the cumulative impact to coral reefs when two or more stressors are present. Therefore, the difference in cumulative impact between sites where there are few pressures and sites where there are many pressures may be larger than presented here. However, Darling et al. [17] reported no synergisms between two stressors to coral 
reefs (fishing pressure and heat stress). Ban et al. [70], reviewing the stressor interactions on coral reefs, also found insufficient empirical evidence to suggest that the prevailing type of stressor interaction was synergistic. In addition, various forms of nonlinear responses to stressors could mean that there is spatial variation in the relative weights of individual stressors used to estimate cumulative impacts.

As predicted, several stressors were clustered in particular areas, leading some reef cells (i.e., about $6.5 \%$ ) to face high levels of risk to cumulative impacts from both local and global stressors. These cells, mostly surrounded by population centres, warrant conservation attention because their ecological functions could be quickly lost in the future. Conversely, a significant amount of coral reef habitat (i.e., $42 \%$ ) could represent new opportunities for protection because they might retain naturally-functioning ecosystems, and hence maintain provision of ecological services over time. Some of these reefs remain as thermal refugia in the future or provide opportunities for adaptation under global warming [25], critical for the occurrence of viable populations of species in the long-term. While the protection of sites under minimal threat can facilitate conservation actions, implementing this sole approach might undermine the effectiveness of conservation measures to benefit biodiversity [71]. With imminent and ongoing changes to coral reef ecosystems, managers and policy makers need to broaden their pathways of action to provide a diversity of tangible and intangible outcomes to biodiversity. Contingent on the available resources, managers might consider responding actively to these requirements by grounding the practice of management in a theoretical framework, such as the one presented here.

We restricted our analysis to the human activities affecting coral reefs for which data were available. Expanding considerations to other threatening processes operating at both local (e.g., tourism) and global scales (e.g., acidification) would therefore likely provide additional insights. Our findings also indicate the locations of areas to focus on for protection, and areas to focus on for restoration/recovery, ecological monitoring, and stress alleviation. Although our theoretical framework can offer new insights into the design of conservation areas for coral reefs considering multiple management objectives, our CIA approach would need to be combined with other criteria (e.g., species representation, connectivity) within a more holistic conservation planning context [72]. Further research should seek to combine information on stressors with data on the state of ecological values and in situ data on impacts within our study area. More generally, we suggest that tools and methods provided here are a valuable source of information for decision-making and can be easily accessible to any coral reef manager. We encourage implementing CIA regionally that generates explicit quantitative relationships between local and global stressors to strengthen its future applications, rather than conducting assessments on a stressor-specific basis.

Supplementary Materials: The following are available online at http:/ /www.mdpi.com/1424-2818/10/2/26/s1, S1: Details on each stressor; Figure S1: Spatial pattern of potential exposure to fishing (a) and land-based activities (b). Panels for reef cells within A-E sectors of the study area correspond to locations presented in Figure 1; Figure S2: Spatial pattern of potential exposure to coastal development (a) and ocean mining (b). Panels for reef cells within A-E sectors of the study area correspond to locations presented in Figure 1; Figure S3: Spatial pattern of potential exposure to aquaculture (shrimp farming) (a) and shipping movements (b). Panels for reef cells within A-E sectors of the study area correspond to locations presented in Figure 1; Figure S4: Spatial pattern of potential exposure to thermal stress. Panels for reef cells within A-E sectors of the study area correspond to locations presented in Figure 1.

Acknowledgments: R.A.M. thanks CNPq-Brazil for financial support and the Chico Mendes Institute for Biodiversity Conservation/Ministry of Environment for general assistance with his PhD. R.A.M. and R.L.P. acknowledge support from the Australian Research Council.

Author Contributions: R.A.M., A.G. and R.L.P. conceived and designed the experiments; R.A.M. performed the experiments; R.A.M. and A.G. analyzed the data; R.A.M. and A.G. contributed reagents/materials/analysis tools; R.A.M., A.G., and R.L.P. wrote the paper.

Conflicts of Interest: The authors declare no conflict of interest. 


\section{References}

1. Bellwood, D.; Hughes, T.; Folke, C.; Nyström, M. Confronting the coral reef crisis. Nature 2004, 429, 827-833. [CrossRef] [PubMed]

2. Hoegh-Guldberg, O.; Mumby, P.J.; Hooten, A.J.; Steneck, R.S.; Greenfield, P.; Gomez, E.; Harvell, C.D.; Sale, P.F.; Edwards, A.J.; Caldeira, K.; et al. Coral reefs under rapid climate change and ocean acidification. Science 2007, 318, 1737-1742. [CrossRef] [PubMed]

3. Hughes, T.P.; Barnes, M.L.; Bellwood, D.R.; Cinner, J.E.; Cumming, G.S.; Jackson, J.B.C.; Kleypas, J.; van de Leemput, I.A.; Lough, J.M.; Morrison, T.H.; et al. Coral reefs in the Anthropocene. Nature 2017, 546, 82-90. [CrossRef] [PubMed]

4. Mora, C.; Andréfouët, S.; Costello, M.J.; Kranenburg, C.; Rollo, A.; Veron, J.; Gaston, K.J.; Myers, R.A. Coral reefs and the global network of marine protected areas. Science 2006, 312, 1750-1751. [CrossRef] [PubMed]

5. Cinner, J.E.; Huchery, C.; MacNeil, M.A.; Graham, N.A.J.; McClanahan, T.R.; Maina, J.; Maire, E.; Kittinger, J.N.; Hicks, C.C.; Mora, C.; et al. Bright spots among the world's coral reefs. Nature 2016, 535, 416-419. [CrossRef] [PubMed]

6. Van Hooidonk, R.; Maynard, J.; Tamelander, J.; Gove, J.; Ahmadia, G.; Raymundo, L.; Williams, G.; Heron, S.F.; Planes, S. Local-scale projections of coral reef futures and implications of the Paris Agreement. Sci. Rep. 2016, 6, 39666. [CrossRef] [PubMed]

7. Hughes, T.P.; Baird, A.H.; Bellwood, D.R.; Card, M.; Connolly, S.R.; Folke, C.; Grosberg, R.; Hoegh-Guldberg, O.; Jackson, J.; Kleypas, J. Climate change, human impacts, and the resilience of coral reefs. Science 2003, 301, 929-933. [CrossRef] [PubMed]

8. Donner, S.D.; Potere, D. The inequity of the global threat to coral reefs. Bioscience 2007, 57, 214-215. [CrossRef]

9. Pratchett, M.S.; Munday, P.L.; Wilson, S.K.; Graham, N.A.J.; Cinner, J.E.; Bellwood, D.R.; Jones, G.P.; Polunin, N.V.C.; McClanahan, T.R. Effects of climate-induced coral bleaching on coral-reef fishes-Ecological and economic consequences. Oceanogr. Mar. Biol. Annu. Rev. 2008, 46, 251-296.

10. McClanahan, T.R.; Donner, S.D.; Maynard, J.A.; MacNeil, M.A.; Graham, N.A.; Maina, J.; Baker, A.C.; Beger, M.; Campbell, S.J.; Darling, E.S. Prioritizing key resilience indicators to support coral reef management in a changing climate. PLoS ONE 2012, 7, e42884. [CrossRef] [PubMed]

11. Baker, A.C.; Glynn, P.W.; Riegl, B. Climate change and coral reef bleaching: An ecological assessment of long-term impacts, recovery trends and future outlook. Estuar. Coast. Shelf Sci. 2008, 80, 435-471. [CrossRef]

12. Makino, A.; Yamano, H.; Beger, M.; Klein, C.J.; Yara, Y.; Possingham, H.P. Spatio-temporal marine conservation planning to support high-latitude coral range expansion under climate change. Divers. Distrib. 2014, 20, 1-13. [CrossRef]

13. Bruno, J.F.; Selig, E.R.; Casey, K.S.; Page, C.A.; Willis, B.L.; Harvell, C.D.; Sweatman, H.; Melendy, A.M. Thermal stress and coral cover as drivers of coral disease outbreaks. PLoS Biol. 2007, 5, e124. [CrossRef] [PubMed]

14. Munday, P.; Leis, J.; Lough, J.; Paris, C.; Kingsford, M.; Berumen, M.; Lambrechts, J. Climate change and coral reef connectivity. Coral Reefs 2009, 28, 379-395. [CrossRef]

15. Magris, R.A.; Pressey, R.L.; Weeks, R.; Ban, N.C. Integrating connectivity and climate change into marine conservation planning. Biol. Conserv. 2014, 170, 207-221. [CrossRef]

16. Graham, N.A.; Chabanet, P.; Evans, R.D.; Jennings, S.; Letourneur, Y.; Aaron MacNeil, M.; McClanahan, T.R.; Öhman, M.C.; Polunin, N.V.; Wilson, S.K. Extinction vulnerability of coral reef fishes. Ecol. Lett. 2011, 14, 341-348. [CrossRef] [PubMed]

17. Darling, E.S.; McClanahan, T.R.; Côté, I.M. Combined effects of two stressors on kenyan coral reefs are additive or antagonistic, not synergistic. Conserv. Lett. 2010, 3, 122-130. [CrossRef]

18. Humanes, A.; Ricardo, G.F.; Willis, B.L.; Fabricius, K.E.; Negri, A.P. Cumulative effects of suspended sediments, organic nutrients and temperature stress on early life history stages of the coral Acropora tenuis. Sci. Rep. 2017, 7, 44101. [CrossRef] [PubMed]

19. Côté, I.M.; Darling, E.S.; Brown, C.J. Interactions among ecosystem stressors and their importance in conservation. Proc. R. Soc. B 2016, 283, 20152592. [CrossRef] [PubMed] 
20. Brown, C.J.; Saunders, M.I.; Possingham, H.P.; Richardson, A.J. Interactions between global and local stressors of ecosystems determine management effectiveness in cumulative impact mapping. Divers. Distrib. 2014, 20, 538-546. [CrossRef]

21. Brown, C.J.; Saunders, M.I.; Possingham, H.P.; Richardson, A.J. Managing for interactions between local and global stressors of ecosystems. PLoS ONE 2013, 8, e65765. [CrossRef] [PubMed]

22. Halpern, B.S.; Walbridge, S.; Selkoe, K.A.; Kappel, C.V.; Micheli, F.; D’Agrosa, C.; Bruno, J.F.; Casey, K.S.; Ebert, C.; Fox, H.E.; et al. A global map of human impact on marine ecosystems. Science 2008, $319,948$. [CrossRef] [PubMed]

23. Halpern, B.S.; Frazier, M.; Potapenko, J.; Casey, K.S.; Koenig, K.; Longo, C.; Lowndes, J.S.; Rockwood, R.C.; Selig, E.R.; Selkoe, K.A.; et al. Spatial and temporal changes in cumulative human impacts on the world/'s ocean. Nat. Commun. 2015, 6, 7615. [CrossRef] [PubMed]

24. Loiola, M.; Oliveira, M.D.; Kikuchi, R.K. Tolerance of Brazilian brain coral Mussismilia braziliensis to sediment and organic matter inputs. Mar. Pollut. Bull. 2013, 77, 55-62. [CrossRef] [PubMed]

25. Magris, R.; Heron, S.F.; Pressey, R.L. Conservation planning for coral reefs accounting for climate warming disturbances. PLoS ONE 2015, 10, e0140828. [CrossRef] [PubMed]

26. Tedesco, E.C.; Segal, B.; Calderon, E.N.; Schiavetti, A. Conservation of Brazilian coral reefs in the Southwest Atlantic Ocean: A change of approach. Lat. Am. J. Aquat. Res. 2017, 45, 228-245. [CrossRef]

27. Bender, M.; Floeter, S.; Mayer, F.; Vila-Nova, D.; Longo, G.; Hanazaki, N.; Carvalho-Filho, A.; Ferreira, C. Biological attributes and major threats as predictors of the vulnerability of species: A case study with brazilian reef fishes. Oryx 2013, 47, 259-265. [CrossRef]

28. Leão, Z.M.A.N.; Dominguez, J.M.L. Tropical coast of Brazil. Mar. Pollut. Bull. 2000, 41, 112-122. [CrossRef]

29. Magris, R.A.; Pressey, R.L.; Mills, M.; Vila-Nova, D.A.; Floeter, S. Integrated conservation planning for coral reefs: Designing conservation zones for multiple conservation objectives in spatial prioritisation. Glob. Ecol. Conserv. 2017, 11, 53-68. [CrossRef]

30. Heron, S.F.; Maynard, J.A.; Ruben van Hooidonk, C. Warming trends and bleaching stress of the world's coral reefs 1985-2012. Sci. Rep. 2016, 6, 38402. [CrossRef] [PubMed]

31. Magris, R.A.; Bond-Buckup, G.; Magalhães, C.; Mantelatto, F.L.; Reid, J.W.; Loureiro, L.M.A.E.-m.; Coelho, P.A.; Santana, W.R.A.; Buckup, L.; Rocha, S.S.d. Quantification of extinction risk for crustacean species: An overview of the national red listing process in Brazil. Nauplius 2010, 129-135.

32. Bender, M.; Floeter, S.; Hanazaki, N. Do traditional fishers recognise reef fish species declines? Shifting environmental baselines in eastern Brazil. Fish. Manag. Ecol. 2013, 20, 58-67. [CrossRef]

33. Giglio, V.J.; Luiz, O.J.; Schiavetti, A. Recreational diver behavior and contacts with benthic organisms in the Abrolhos national marine park, Brazil. Environ. Manag. 2016, 57, 637-648. [CrossRef] [PubMed]

34. Mouillot, D.; Graham, N.A.; Villéger, S.; Mason, N.W.; Bellwood, D.R. A functional approach reveals community responses to disturbances. Trends Ecol. Evol. 2013, 28, 167-177. [CrossRef] [PubMed]

35. Spalding, M.D.; Brown, B.E. Warm-water coral reefs and climate change. Science 2015, 350, 769. [CrossRef] [PubMed]

36. Wilson, K.; Pressey, R.L.; Newton, A.; Burgman, M.; Possingham, H.; Weston, C. Measuring and incorporating vulnerability into conservation planning. Environ. Manag. 2005, 35, 527-543. [CrossRef] [PubMed]

37. Jones, G.; Almany, G.; Russ, G.; Sale, P.; Steneck, R.; Van Oppen, M.; Willis, B. Larval retention and connectivity among populations of corals and reef fishes: History, advances and challenges. Coral Reefs 2009, 28, 307-325. [CrossRef]

38. Magris, R.A.; Treml, E.A.; Pressey, R.L.; Weeks, R. Integrating multiple species connectivity and habitat quality into conservation planning for coral reefs. Ecography 2016, 39, 649-664. [CrossRef]

39. Erftemeijer, P.L.; Riegl, B.; Hoeksema, B.W.; Todd, P.A. Environmental impacts of dredging and other sediment disturbances on corals: A review. Mar. Pollut. Bull. 2012, 64, 1737-1765. [CrossRef] [PubMed]

40. Venter, O.; Sanderson, E.W.; Magrach, A.; Allan, J.R.; Beher, J.; Jones, K.R.; Possingham, H.P.; Laurance, W.F.; Wood, P.; Fekete, B.M. Sixteen years of change in the global terrestrial human footprint and implications for biodiversity conservation. Nat. Commun. 2016, 7, 12558. [CrossRef] [PubMed]

41. Venter, O.; Sanderson, E.W.; Magrach, A.; Allan, J.R.; Beher, J.; Jones, K.R.; Possingham, H.P.; Laurance, W.F.; Wood, P.; Fekete, B.M. Global terrestrial human footprint maps for 1993 and 2009. Sci. Data 2016, 3, 160067. [CrossRef] [PubMed] 
42. Munday, P.L. Habitat loss, resource specialization, and extinction on coral reefs. Glob. Chang. Biol. 2004, 10, 1642-1647. [CrossRef]

43. Fabricius, K.E. Effects of terrestrial runoff on the ecology of corals and coral reefs: Review and synthesis. Mar. Pollut. Bull. 2005, 50, 125-146. [CrossRef] [PubMed]

44. Aubrecht, C.; Elvidge, C.; Longcore, T.; Rich, C.; Safran, J.; Strong, A.; Eakin, C.; Baugh, K.; Tuttle, B.; Howard, A. A global inventory of coral reef stressors based on satellite observed nighttime lights. Geocarto Int. 2008, 23, 467-479. [CrossRef]

45. Pulfrich, A.; Branch, G.M. Effects of sediment discharge from namibian diamond mines on intertidal and subtidal rocky-reef communities and the rock lobster Jasus lalandii. Estuar. Coast. Shelf Sci. 2014, 150, 179-191. [CrossRef]

46. Hatje, V.; de Souza, M.M.; Ribeiro, L.F.; Eca, G.F.; Barros, F. Detection of environmental impacts of shrimp farming through multiple lines of evidence. Environ. Pollut. 2016, 219, 672-684. [CrossRef] [PubMed]

47. Magris, R.A.; Barreto, R. Mapping and assessment of protection of mangrove habitats in Brazil. Pan-Am. J. Aquat. Sci. 2010, 5, 546-556.

48. Grech, A.; Bos, M.; Brodie, J.; Coles, R.; Dale, A.; Gilbert, R.; Hamann, M.; Marsh, H.; Neil, K.; Pressey, R. Guiding principles for the improved governance of port and shipping impacts in the Great Barrier Reef. Mar. Pollut. Bull. 2013, 75, 8-20. [CrossRef] [PubMed]

49. Rowlands, G.; Purkis, S.; Riegl, B.; Metsamaa, L.; Bruckner, A.; Renaud, P. Satellite imaging coral reef resilience at regional scale. A case-study from Saudi Arabia. Mar. Pollut. Bull. 2012, 64, 1222-1237. [CrossRef] [PubMed]

50. Ban, N.; Alder, J. How wild is the ocean? Assessing the intensity of anthropogenic marine activities in British Columbia, Canada. Aquat. Conserv. 2008, 18, 55-85. [CrossRef]

51. Halpern, B.S.; Kappel, C.V.; Selkoe, K.A.; Micheli, F.; Ebert, C.M.; Kontgis, C.; Crain, C.M.; Martone, R.G.; Shearer, C.; Teck, S.J. Mapping cumulative human impacts to California current marine ecosystems. Conserv. Lett. 2009, 2, 138-148. [CrossRef]

52. Crain, C.M.; Kroeker, K.; Halpern, B.S. Interactive and cumulative effects of multiple human stressors in marine systems. Ecol. Lett. 2008, 11, 1304-1315. [CrossRef] [PubMed]

53. Halpern, B.S.; Selkoe, K.A.; Micheli, F.; Kappel, C.V. Evaluating and ranking the vulnerability of global marine ecosystems to anthropogenic threats. Conserv. Biol. 2007, 21, 1301-1315. [CrossRef] [PubMed]

54. Tulloch, V.J.; Tulloch, A.I.; Visconti, P.; Halpern, B.S.; Watson, J.E.; Evans, M.C.; Auerbach, N.A.; Barnes, M.; Beger, M.; Chadès, I. Why do we map threats? Linking threat mapping with actions to make better conservation decisions. Front. Ecol. Environ. 2015, 13, 91-99. [CrossRef]

55. Leão, Z.; Kikuchi, R.; Oliveira, M.D.M.; Vasconcellos, V. Status of eastern Brazilian coral reefs in time of climate changes. Pan-Am. J. Aquat. Sci. 2010, 5, 224-235.

56. Francini-Filho, R.B.; Moura, R.L.; Thompson, F.L.; Reis, R.M.; Kaufman, L.; Kikuchi, R.K.; Leão, Z.M. Diseases leading to accelerated decline of reef corals in the largest south atlantic reef complex (Abrolhos bank, eastern Brazil). Mar. Pollut. Bull. 2008, 56, 1008-1014. [CrossRef] [PubMed]

57. Francini-Filho, R.; Moura, R.L. Evidence for spillover of reef fishes from a no-take marine reserve: An evaluation using the before-after control-impact (BACI) approach. Fish. Res. 2008, 93, 346-356. [CrossRef]

58. Barreto, R.; Bornatowski, H.; Motta, F.; Santander-Neto, J.; Vianna, G.; Lessa, R. Rethinking use and trade of pelagic sharks from Brazil. Mar. Policy 2017, 85, 114-122. [CrossRef]

59. Giglio, V.; Luiz, O.; Gerhardinger, L. Depletion of marine megafauna and shifting baselines among artisanal fishers in eastern Brazil. Anim. Conserv. 2015, 18, 348-358. [CrossRef]

60. Selkoe, K.; Halpern, B.; Ebert, C.; Franklin, E.; Selig, E.; Casey, K.; Bruno, J.; Toonen, R. A map of human impacts to a "pristine" coral reef ecosystem, the Papahānaumokuākea marine national monument. Coral Reefs 2009, 28, 635-650. [CrossRef]

61. Ban, N.C.; Alidina, H.M.; Ardron, J.A. Cumulative impact mapping: Advances, relevance and limitations to marine management and conservation, using Canada's Pacific waters as a case study. Mar. Policy 2010, 34, 876-886. [CrossRef]

62. Stelzenmüller, V.; Lee, J.; Garnacho, E.; Rogers, S. Assessment of a bayesian belief network-gis framework as a practical tool to support marine planning. Mar. Pollut. Bull. 2010, 60, 1743-1754. [CrossRef] [PubMed]

63. Stelzenmüller, V.; Lee, J.; South, A.; Rogers, S.I. Quantifying cumulative impacts of human pressures on the marine environment: A geospatial modelling framework. Mar. Ecol. Prog. Ser. 2010, 398, 19-32. [CrossRef] 
64. Grech, A.; Coles, R.; Marsh, H. A broad-scale assessment of the risk to coastal seagrasses from cumulative threats. Mar. Policy 2011, 35, 560-567. [CrossRef]

65. Halpern, B.S.; Fujita, R. Assumptions, challenges, and future directions in cumulative impact analysis. Ecosphere 2013, 4, 1-11. [CrossRef]

66. Ban, S.S.; Pressey, R.L.; Graham, N.A. Assessing interactions of multiple stressors when data are limited: A bayesian belief network applied to coral reefs. Glob. Environ. Chang. 2014, 27, 64-72. [CrossRef]

67. Teck, S.J.; Halpern, B.S.; Kappel, C.V.; Micheli, F.; Selkoe, K.A.; Crain, C.M.; Martone, R.; Shearer, C.; Arvai, J.; Fischhoff, B. Using expert judgment to estimate marine ecosystem vulnerability in the California current. Ecol. Appl. 2010, 20, 1402-1416. [CrossRef] [PubMed]

68. Martin, T.G.; Burgman, M.A.; Fidler, F.; Kuhnert, P.M.; Low-Choy, S.; McBride, M.; Mengersen, K. Eliciting expert knowledge in conservation science. Conserv. Biol. 2012, 26, 29-38. [CrossRef] [PubMed]

69. Drescher, M.; Perera, A.; Johnson, C.; Buse, L.; Drew, C.; Burgman, M. Toward rigorous use of expert knowledge in ecological research. Ecosphere 2013, 4, 1-26. [CrossRef]

70. Ban, S.S.; Graham, N.A.; Connolly, S.R. Evidence for multiple stressor interactions and effects on coral reefs. Glob. Chang. Biol. 2014, 20, 681-697. [CrossRef] [PubMed]

71. Pressey, R.L.; Visconti, P.; Ferraro, P.J. Making parks make a difference: Poor alignment of policy, planning and management with protected-area impact, and ways forward. Phil. Trans. R. Soc. B 2015, 370, 20140280. [CrossRef] [PubMed]

72. Magris, R.A.; Andrello, M.; Pressey, R.L.; Mouillot, D.; Dalongeville, A.; Jacobi, M.N.; Manel, S. Biologically representative and well-connected marine reserves enhance biodiversity persistence in conservation planning. Conserv. Lett. 2018, 11, e12439. [CrossRef]

(C) 2018 by the authors. Licensee MDPI, Basel, Switzerland. This article is an open access article distributed under the terms and conditions of the Creative Commons Attribution (CC BY) license (http:/ / creativecommons.org/licenses/by/4.0/). 